\title{
CORRELATION OF HANDWASHING AND BASIC HOUSEHOLD SANITATION TOWARDS NUTRITIONAL STATUS OF TODDLER (UNDER 2 YEARS OLD/ BADUTA) IN BOJONEGORO DISTRICT Kebiasaan Cuci Tangan, Sanitasi Dasar Dan Hubungannya Dengan Status Gizi Pada Toddler di Kabupaten Bojonegoro
}

\author{
Anizah Izzi Haibah \\ Universitas Airlangga \\ Anizah.izzi.haibah-2017@fkm.unair.ac.id
}

\section{ARTICLE INFO \\ Article History: \\ Received: \\ February, 2 ${ }^{\text {nd }}, 2021$ \\ Revised: \\ April, 8 ${ }^{\text {th }}, 2021$ \\ Accepted: \\ August, $9^{\text {th }}, 2021$ \\ Published online \\ March, $1^{\text {st }}, 2022$}

\begin{abstract}
Background: Nutrition problems in toddlers are still a significant problem both on a global and local scale. Intensive monitoring of nutritional status and controlling various factors related to nutritional status is very important to be done especially in the critical period that is before the child is two years old (Toddler/Baduta). Objective: Analyze the relationship of mother/main caregiver's handwashing and basic household sanitation with the nutritional status of Toddler (under two years old/Baduta) in Mojosari Village, Bojonegoro. Method: This research was a descriptive-analytic with a crosssectional design with the target is the entire population of Toddler (under two years old) that meets the inclusion and exclusion criteria. Data collection was done by questionnaire and observation. Relationship analysis was performed with fisher exact test. Result : This study did not find any significant relationship between hand washing ( $p=1>\alpha(0.05))$ and basic household sanitation $(p=0.2485>\alpha(0.05))$ with nutritional status. Conclusion: The absence of significant relationships that was found in this study was due to the presence of other complex variables related to nutritional status.
\end{abstract}

Keywords : handwashing, sanitation, nutritional status

Latar belakang : Permasalahan gizi pada balita masih menjadi masalah yang signifikan baik pada skala global maupun lokal. Pemantauan intensif terhadap status gizi serta pengendalian berbagai faktor yang berhubungan dengan status gizi merupakan hal yang sangat penting untuk dilakukan terutama pada periode kritis yaitu sebelum anak berusia dua tahun (Baduta). Tujuan : Menganalisis hubungan kebiasaan cuci tangan ibu/pengasuh utama dan sanitasi dasar rumah dengan status gizi pada Toddlerdi Desa Mojosari, Bojonegoro. Metode : Penelitian ini adalah deskriptif analitik dengan desain cross sectional yang sasarannya adalah seluruh populasi Toddleryang memenuhi kriteria inklusi dan eksklusi. Pengumpulan data dilakukan dengan kuesioner dan observasi. Analisis hubungan dilakukan dengan uji fisher exact. Hasil : Penelitiaan ini tidak menemukan adanya hubungan yang signifikan antara kebiasaan cuci tangan $(p=1>\alpha(0,05))$ dan sanitasi dasar rumah $(p=$ $0,2485>\alpha(0,05))$ dengan status gizi. Kesimpulan : Tidak adanya hubungan yang ditemukan pada penelitian dikarenakan adanya variabel kompleks lainnya yang berhubungan dengan status gizi.

Kata kunci: cuci tangan, sanitasi, status gizi 
Anizah. Correlation Of Handwashing And Basic Household Sanitation Towards Nutritional Status Of Toddler (Under 2 Years Old/ Baduta) In Bojonegoro District

\section{INTRDUCTION}

The efforts to improve nutrition problems and maintain nutritional status in children under five are one form of realization of the 2030 Sustainable Development Goals (SDGs). Specifically, this relates to the second goal of the SDGs, namely to eradicate hunger, with one of the targets being eradicate all forms of malnutrition by 2030, and by 2025 can achieve the target of stunting and wasting below the internationally agreed standards. Many forms of intervention at the regional and global levels have been carried out to achieve these targets. However, until now the problem of malnutrition still persists. The progress made from intervention outcomes is still not large enough to meet the targets set by 2025(UNICEF, 2020).

In Indonesia, the prevalence of malnutrition obtained from the Study on the Nutritional Status of Indonesian Toddlers (SSGBI) in 2019 is known to have decreased when compared to the results in RISKESDAS (Basic Health Research) in 2018. Based on these data, the incidence of malnutrition in children under five is $16.29 \%$ (down $1.5 \%$ ), stunting by $27.67 \%$ (down $3.1 \%$ ), and thin by $7.44 \%$ (down 2.8\%) (Izwardy, 2020). Although it has decreased, this figure is still quite high when compared to other countries in ASEAN (Association of Southeast Asian Nations) (World Food Programme, 2020).

Mojosari Village is one of the villages in Bojonegoro Regency with a high prevalence of nutritional problems in toddlers (under 2 years old/ Baduta). Based on the latest data from the local, it is known that the prevalence of underfive children with nutritional problems or those who have the potential to experience nutritional problems is $23 \%$ of the total toddler population. This nutritional problem can have a more severe and long-term impact if it occurs before Toddler. It is because this period is a critical period commonly known as the First 1000 Days of Life which begins during pregnancy (Bappenas, 2019).

In preventing nutritional problems from increasing, it is important to monitor nutritional status as well as understand what factors are related to nutritional status. Factors that may be associated with nutritional status are very diverse. Some of them are hygiene factors (including hand washing habits) and sanitation (Septikasari, 2018). Although these two factors are often considered as simple efforts, there are still many discrepancies in their implementation, especially in rural areas (UNICEF, 2019).

Until now, hygiene and sanitation are still problems that cannot be solved in Indonesia. Access to sanitation is still limited and there are gaps between regions (Afifah $e t$ al., 2018). It is recorded that there are at least 24 million people in Indonesia who experience a lack of clean water and 38 million people have difficulty accessing sanitation (Water Org., 2020).

Research related to the relationship between hand washing habits and basic sanitation with nutritional status has been carried out before. However, in this recent study, the chosen target focused on toddler specifically on babies under two years old and the components studied were the key components that were suspected to be the main problems in the research area. The purpose of this study was to analyze the relationship between mother's hand washing habits and basic home sanitation with nutritional status of toddler (babies under two years old) in Mojosari Village, Bojonegoro Regency.

\section{METHOD}

This research is a descriptive analytic research with a cross sectional approach. The study was located in Mojosari Village, Kalitidu District, Bojonegoro Regency and was carried out in December 2019 - January 2020. The population of this study was toddler (babies under 2 years old/ Baduta) in Mojosari Village. This study used a saturated sampling technique, data collection was carried out on the entire population that meets the specified inclusion and exclusion criteria. Inclusion criteria included infants aged 0-24 months (toddler), having anthropometric records in the $\mathrm{MCH}$ handbook, and the mother/main caregiver of toddler willing to participate in filling out the questionnaire. Exclusion criteria included toddler with genetic disorders that cause impaired growth and development.

Data collection was done by questionnaire and observation. In the questionnaire, each question answered with "Yes" gets a score of 1 and if "no" gets a score of 0 . The independent variables studied were the hand washing habits of the mother/main caregiver and basic home sanitation. The variable of hand washing habits consists of 2 question components and basic home 
Anizah. Correlation Of Handwashing And Basic Household Sanitation Towards Nutritional Status Of Toddler (Under 2 Years Old/ Baduta) In Bojonegoro District

sanitation consists of 5 components. The score for the handwashing habit variable was said to be in the good category if it got a score of 2 and the bad category if the score was <2. On the sanitation variable, the researcher also made observations in the form of qualitative observations on the environment according to predetermined criteria referring to the
Regulation of the Minister of Health Republik Indonesia Number 3 of 2014 concerning Community-Based Total Sanitation (Table 1) with the aim of confirming the correctness of filling out the answers to the questionnaire. The score for the sanitation variable was said to be in the safe category if the score was $>3$ and the unsafe category if the score was $<3$.

Table 1. Variable Observation Criteria for Home Basic Sanitation

\begin{tabular}{|c|l|l|}
\hline No. & \multicolumn{1}{|c|}{ Observed components } & \multicolumn{1}{c|}{ Criteria } \\
\hline 1. & Clean Water & $\begin{array}{l}\text { There is a provision of clean water collectively and on a household } \\
\text { scale }\end{array}$ \\
\hline 2. & Healthy latrine & $\begin{array}{l}\text { There are latrines with the following criteria: } \\
\text { a. The top of the latrine (roof) must be able to protect from outside } \\
\text { weather and other forms of disturbance } \\
\text { b. The drain hole uses a goose neck construction } \\
\text { c. The latrine floor is waterproof and non-slip } \\
\text { d. There is a septic tank }\end{array}$ \\
\hline 3. & Wastewater Sewer & $\begin{array}{l}\text { There is Wastewater Sewer with the following criteria: } \\
\text { a. Have different sewers between latrine wastewater and other } \\
\text { wastewater (kitchen waste water, washing, etc. })\end{array}$ \\
& & $\begin{array}{l}\text { b. The channel is closed, does not pollute the surroundings and does } \\
\text { not cause puddles } \\
\text { c. Doesn't smell } \\
\text { d. Connected to infiltration wells or public sewers }\end{array}$ \\
\hline 4. & Trash can & $\begin{array}{l}\text { There is a trash can with the following criteria: } \\
\text { a. The number of trash cans is sufficient to accommodate the waste } \\
\text { generated } \\
\text { b. The trash can has a lid } \\
\text { c. Doesn't smell } \\
\text { d. No breeding of vectors or other animals }\end{array}$ \\
& & $\begin{array}{l}\text { There is Temporary Garbage Dump/Landfill around the area where } \\
\text { you live }\end{array}$ \\
\hline 5. & $\begin{array}{l}\text { Temporary Garbage } \\
\text { Dump/Landfill }\end{array}$ &
\end{tabular}

The dependent variable in this study was the nutritional status of toddlers (under 2 years old/ Baduta) with body weight/length index. This variable was obtained from the results of a questionnaire related to weight and body length which was filled in based on the results of measurements at the Integrated Healthcare Posts in that month according to data collection in the $\mathrm{MCH}$ book (Maternal and Child Health). Processing of data related to the nutritional status of Toddlerusing the WHO Anthro application to determine the Z-score value. The grouping of nutritional status is based on the Minister of Health Regulation Number 2 of 2020 where nutritional status with an index of $\mathrm{BB} / \mathrm{PB}$ is divided into six categories, namely Obesity (> +3SD), Overnutrition $(>+2 \mathrm{SD}$ to $+3 \mathrm{SD})$, Risk of Overnutrition $(>+1 \mathrm{SD}$ to $+2 \mathrm{SD})$, Good nutrition (-2SD to +1SD), Poor nutrition (-3SD to <-2SD) and Poor nutrition (<-3SD).
Data analysis was carried out in the form of univariate and bivariate descriptive analysis using the Fisher exact test to determine the relationship between the independent and dependent variables. In the bivariate analysis, the grouping of nutritional status was compressed into 2 categories in order to meet the requirements to use the Fisher's test. Categorization of undernutrition/bad nutrition if they have poor nutritional status and poor nutrition, while good/over nutrition category if they have good nutritional status, are at risk of overnutrition, overnutrition and obesity.

Data analysis was carried out with the help of the Epi Info 7 application. This research has received an ethical certificate from the Health Research Ethics 
Anizah. Correlation Of Handwashing And Basic Household Sanitation Towards Nutritional Status Of Toddler (Under 2 Years Old/ Baduta) In Bojonegoro District

Committee of the Faculty of Nursing, Universitas Airlangga number 1769-KEPK in September 2019.

\section{RESULTS}

Characteristics and Nutritional Status of Toddlers (under two years old)

Based on the univariate analysis of Toddler (under two years old) characteristics
(Table 5), the majority of Toddler were female $(56.36 \%)$ and aged $9-16$ months $(36.36 \%)$. The majority of Toddler already have good nutritional status (80\%). There are Toddler who are at risk of overnutrition as much as $10.91 \%$, and undernutrition as much as $3.64 \%$. As for the other groupings, namely poor nutrition, overweight and obesity, the numbers are the same, namely $1.82 \%$ each.

Table 2. Characteristics of Toddler (under 2 years old)

\begin{tabular}{|l|c|c|}
\hline Variable & Amount & Percentage \\
\hline Sex & 31 & $56.36 \%$ \\
\hline Female & 24 & $43.64 \%$ \\
\hline Male & 19 & $34.55 \%$ \\
\hline Age & 20 & $36.36 \%$ \\
\hline 0-8 Months & 16 & $29.09 \%$ \\
\hline 9-16 Months & \multicolumn{2}{|l|}{} \\
\hline 17-24 Months & 1 & $1.82 \%$ \\
\hline Nutritional Status & 2 & $3.64 \%$ \\
\hline Under nutrition & 44 & $80 \%$ \\
\hline Poor Nutrition & 6 & $10.91 \%$ \\
\hline Good Nutrition & 1 & $1.82 \%$ \\
\hline At risk of overnutrition & 1 & $1.82 \%$ \\
\hline Overweight & $\mathbf{5 5}$ & $\mathbf{1 0 0 \%}$ \\
\hline Obese & \multicolumn{2}{|l}{} \\
\hline Total & \multicolumn{2}{|l|}{} \\
\hline
\end{tabular}

\section{Hand Washing Habits}

Based on the univariate analysis related to the variable of hand washing habits (table 3), it was found that all mothers/main caregivers of Toddler (under two years old) $(100 \%)$ had carried out the habit of washing hands regularly at critical times, namely at least every before and after eating and cooking, after urinating and defecate. The majority (63.64\%) have also used soap when washing their hands. However, there are still some who do not use soap (only running water) when washing their hands, which was $36.36 \%$. The results of the categorization of scores on the variable of hand washing habits obtained as much as $63.64 \%$ had hand washing habits in the good category. While the rest, which is $36.36 \%$ of houses have a bad habit of washing hands.

Table 3. Univariate Analysis of Hand Washing Habits Variables

\begin{tabular}{|l|c|c|}
\hline Variable & \multicolumn{2}{c|}{ Potal } \\
\hline Washing hands regularly at critical times & 55 & $100 \%$ \\
\hline Yes & 35 & $63.64 \%$ \\
\hline Washing Hands Using Soap & 20 & $36.36 \%$ \\
\hline Yes & & \\
\hline No & 35 & $63.64 \%$ \\
\hline Categorization of Hand-Washing Habits Score & 20 & $36.36 \%$ \\
\hline Good & $\mathbf{5 5}$ & $\mathbf{1 0 0 \%}$ \\
\hline Poor & & \\
\hline Total &
\end{tabular}


Anizah. Correlation Of Handwashing And Basic Household Sanitation Towards Nutritional Status Of Toddler (Under 2 Years Old/ Baduta) In Bojonegoro District

\section{Home Basic Sanitation}

In the basic house sanitation variable (Table 4), there were 5 basic components that became the focus of the research: the availability of clean water, the availability of healthy latrines, the availability of sanitary SPAL, the availability of sanitary waste bins, and the availability of TPS/TPA. All respondents were known to have clean water $(100 \%)$. The component of the availability of healthy latrines was owned by $98.8 \%$ of respondents. The sanitary SPAL component was owned by more than half of the respondents, specifically 28 houses (50.91\%). Meanwhile, regarding the components of the trash can and TPS, there were many houses that remained unmet requirements, with $92.73 \%$ each. Based on the results of the calculation of scores on the home sanitation variable, it was known that most of the respondents have sanitation that is classified in the safe category, specifically 31 houses $(56.36 \%)$. A total of 24 other houses (43.64\%) obtained a sanitation score that was classified as

unsafe.

Table 4. Univariate Analysis of Home Basic Sanitation Variables

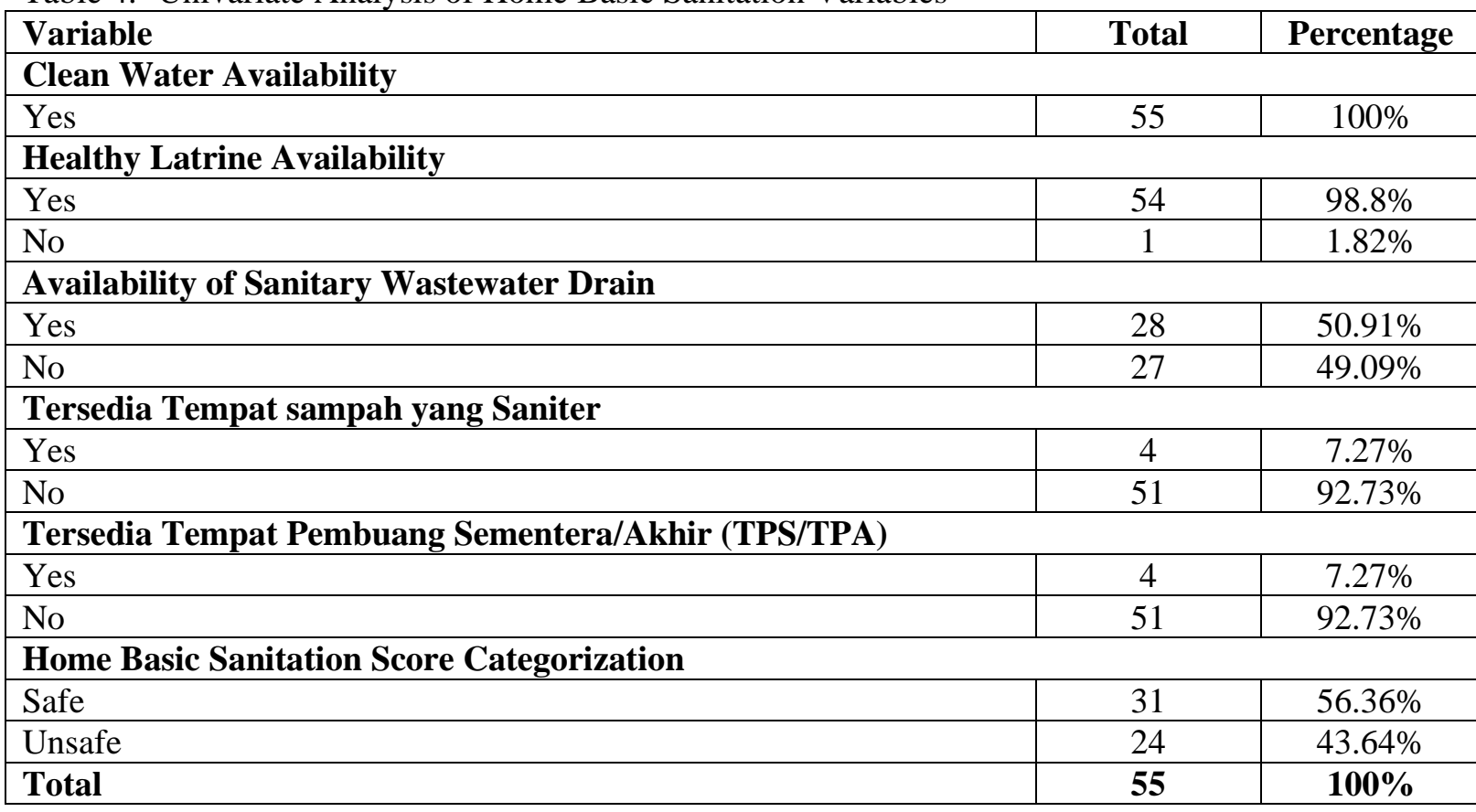

Correlation between Handwashing and Home Sanitation Habits with Toddler's Nutritional Status

In the bivariate analysis, the nutritional status group of children under two were grouped into less/poor nutritional status, as many as 3 children (5.46\%) while the remaining 52 children $(94.64 \%)$ were classified as good/over nutritional status. Based on the results of the bivariate analysis (table 5), it is known that there is a fairly similar pattern between the Toddler group and the main mother/caregiver whose hand washing habits are good or those who are still bad. In these two conditions, the majority of Toddler had good or more nutritional status. Analysis of the relationship between hand washing habits and nutritional status, obtained a P-value of $1.0>(0.05)$, which means that there is no relationship between hand washing habits and nutritional status.

Bivariate analysis related to sanitation and nutritional status found that the majority of Toddler $(90.32 \%)$ with good/more nutrition had home sanitation that was classified as safe. This study also found that even in unsafe sanitation conditions, all toddlers were in the category of good/over nutrition status. Analysis of the relationship between basic home sanitation and nutritional status, obtained a P-value of $0.2485>(0.05)$ which indicates there is no relationship between home sanitation and nutritional status. 
Anizah. Correlation Of Handwashing And Basic Household Sanitation Towards Nutritional Status Of Toddler (Under 2 Years Old/ Baduta) In Bojonegoro District
JPH RECODE March 2022; 5 (2): 62-72

http://e-journal.unair.ac.id/JPHRECODE

http://dx.doi.org/10.20473/jphrecode.v5i2.25198

Table 5. Bivariate Analysis of Handwashing and Basic Sanitation Habits with Toddler's Nutritional Status

\begin{tabular}{|c|c|c|c|c|c|}
\hline \multirow{2}{*}{ Variable } & \multirow{2}{*}{ Category } & \multicolumn{2}{|c|}{ Nutritional Status } & \multirow{2}{*}{ Total } & \multirow{2}{*}{$\begin{array}{c}\mathbf{P} \\
\text { Value }\end{array}$} \\
\hline & & $\begin{array}{c}\text { Good/exceeded } \\
\text { nutrition }\end{array}$ & $\begin{array}{c}\text { Poor/lack of } \\
\text { nutrition }\end{array}$ & & \\
\hline \multirow{2}{*}{$\begin{array}{l}\text { Handwashing } \\
\text { Habit }\end{array}$} & Good & $\begin{array}{c}33 \\
(94.29 \%)\end{array}$ & $\begin{array}{c}2 \\
(5.71 \%)\end{array}$ & $\begin{array}{c}35 \\
(100 \%)\end{array}$ & \multirow{2}{*}{1.0} \\
\hline & Poor & $\begin{array}{c}19 \\
(95 \%)\end{array}$ & $\begin{array}{c}1 \\
(5 \%)\end{array}$ & $\begin{array}{c}20 \\
(100 \%)\end{array}$ & \\
\hline \multirow{2}{*}{$\begin{array}{l}\text { Basic home } \\
\text { sanitation }\end{array}$} & Safe & $\begin{array}{c}28 \\
(90.32 \%)\end{array}$ & $\begin{array}{c}3 \\
9.68 \%\end{array}$ & $\begin{array}{c}31 \\
(100 \%)\end{array}$ & \multirow{2}{*}{0.2485} \\
\hline & Unsafe & $\begin{array}{c}24 \\
(100 \%)\end{array}$ & 0 & $\begin{array}{c}24 \\
(100 \%)\end{array}$ & \\
\hline
\end{tabular}

\section{DISCUSSION}

\section{Toddler's Characteristics}

The majority of toddlers in Mojosari Village are female with various age distributions. Meanwhile, for the nutritional status of toddlers based on the BB/PB index, $5.46 \%$ of toddlers were classified as having poor nutritional status (wasting). The BB/PB index used in this study serves to provide an overview of the suitability of body weight for growth in body length in children. The criteria for classifying nutritional status as less/poor is if the index measurement is $<-2 \mathrm{SD}$. This condition is often caused by disease or lack of nutritional intake that occurs acutely or chronically. Specific interventions must be given to children with these criteria with the aim of preventing the occurrence of severity and dealing with nutritional problems appropriately (Kementrian Kesehatan Republik Indonesia, 2020).

Nutritional status is an indicator of body condition as a result of various complex factors. In general, factors that affect nutritional status in toddlers are divided into direct, indirect and underlying causes. Direct causes include food intake and health status. Indirect causes include family food security, parenting patterns, child health services and environmental factors. While the underlying causes are broader in scope including institutional, political, economic, and social (The World Bank, 2013; Septikasari, 2018). Other factors that were found to be significantly related to nutritional status included mother's education and knowledge, number of children in the family, and family economic status (Suryani, 2017).

\section{Handwashing Habit}

Washing hands regularly, especially at critical times (every time before and after eating, after urinating, defecating and cooking) can prevent disease transmission by interfering with the transmission of infectious agents into the body. In this study, it is known that the habit of washing hands regularly has been carried out by all mothers/main caregivers of toddlers. This finding contradicts a study conducted in 6 cities in Indonesia where it was found that the prevalence of hand washing at critical times was still very low because respondents tended to wash their hands only if they felt their hands were dirty, especially after eating and after cleaning children's feces (Hirai et al., 2016). Factors that significantly affect hand washing habits at critical times are knowledge, attitudes, and water availability (Dagne et al., 2019)

Although all respondents have been washing their hands regularly, in practice, there are still many who do not use soap when washing their hands. In fact, washing hands with soap is an important component that is effective in preventing the transmission of various diseases, especially infections (Freeman et al., 2014). In one study related to the effectiveness of hand washing, it was found that there was a significant difference in the number of bacteria remaining after washing hands with various types of hand washing materials. In this study, it was found that there was a decrease in the number of bacteria after 
Anizah. Correlation Of Handwashing And Basic Household Sanitation Towards Nutritional Status Of Toddler (Under 2 Years Old/ Baduta) In Bojonegoro District

washing hands with soap by $87.3 \%$ whereas when using running water only the decrease was only 58.4\% (Wulansari dan Parut, 2019).

The determinants that significantly influence the behavior of washing hands with soap include the desire to smell good, interpersonal influence, the presence of a hand washing place in close proximity, and most importantly when hands feel dirty (Hirai et al., 2016). In general, according to the Theory of Planned Behavior, a behavior was obtained from the result of the intention/intention to behave which was influenced by determinants in the form of behavioral beliefs, normative beliefs, and control beliefs. In achieving changes in hand washing behavior, these three factors need to be met.

\section{Basic Home Sanitation}

The availability of clean water is the only sanitation variable that has been fulfilled by all respondents. Based on data from the profile of Mojosari Village, clean water in the community is already well available where the majority of its sources come from drilled wells. The availability of clean water is a very important variable, considering that water is a source of life that will never be separated from all human activities. In one study, it was found that the availability of clean water in the household was related to the mother's habit of treating water before using it. Furthermore, this can reduce the possibility of diarrhea and other diseases that can infect family members, including children (Komarulzaman, Smits dan de Jong, 2017).

Based on information from local health workers, Mojosari Village is a village that has been Open Defecation Free (ODF), all of its people have access to latrines. However, based on the results of the study, it is known that there are still houses that have latrines that do not meet the criteria for healthy latrines. Factors that influence healthy latrine ownership include family income, knowledge and attitudes (Novitry dan Agustin, 2017; Widyastutik, 2017).

There are still a lot of respondents who find waste water disposal channels (SPAL) that are not sanitary. In a previous study that was also conducted in Bojonegoro Regency, precisely in Payaman Village, it was found that many residents still did not have SPAL thus the wastewater was disposed of without prior treatment and flowed into the yard around the house or to the pond. This causes odors, environmental pollution, and disturbing environmental aesthetics (Celesta dan Fitriyah, 2019). Factors related to SPAL ownership include knowledge, education, income, and length of work (Meliyanti, 2018).

In addition to waste water disposal, solid waste disposal also needs to be considered. The trash can variable is one of the sanitation variables that plays an important role in preventing various losses and illnesses in the community and is closely related to solid waste disposal. The majority of the trash bin variables found in this study were not sanitary. The number of trash bins is often in accordance with the amount of waste produced in each house, but the condition of the trash bins is still bad. This finding is similar to research in Payaman Village, Bojonegoro which found that the use of the trash bins used was only in the form of a waste basket and did not have a lid (Celesta dan Fitriyah, 2019).

Commonly, the next step for home-scale waste disposal is to distribute it to a disposal site, namely TPS or TPA. However, (Celesta dan Fitriyah, 2019). it was found in this study that the majority of houses stated that there were no nearby TPS or TPA, the Mojosari Village also confirmed that there were no waste disposal facilities for the community. The nearest dumpsite is located on the highway with a considerable distance from people's homes. The absence of waste disposal facilities tends to lead to the habit of littering. In a study, it was known that there is a strong correlation between the availability of waste disposal facilities and the habit of disposing of waste in the community (Kristiana, 2019). Moreover, this results in increased air pollution, causing unpleasant odors and increasing vector density, especially flies, thereby disrupting community activities (Hariyanto dan Ariyani, 2014). Besides that, the unavailability of TPS/TPA in Mojosari Village causes the community to carry out final processing of waste by burning. This has the potential to cause various other health problems, especially ARI (Acute Respiratory Infection).

\section{Relationship between Handwashing Habits and Basic Home Sanitation and Nutritional Status of Toddler (under two years old)}

The results of this study found that there was no relationship between the two independent 
Anizah. Correlation Of Handwashing And Basic Household Sanitation Towards Nutritional Status Of Toddler (Under 2 Years Old/ Baduta) In Bojonegoro District

variables, namely the habit of washing the hands of the mother/main caregiver and basic home sanitation and the nutritional status of toddler (under two years old). These results are in line with previous studies which also found no significant relationship between hand washing habits (Langford, Lunn dan Brick, 2011), sanitation (Sinharoy et al., 2016; Shrestha, Vicendese dan Erbas, 2020), and nutritional status. However, there are also several contradictory studies and actually found a significant correlation between hand washing habits (Shrestha, Vicendese dan Erbas, 2020) and sanitation (Raihan et al., 2017; van Cooten et al., 2019) and nutritional status. The differences in the results found in each study may be caused by several things, one of them is the difference in the methods used. In this study, data collection related to hand washing was carried out using a questionnaire, emphasizing regular hand washing, and the use of soap. These two things are important points of the habit of washing hands, but they have not been able to represent the practice of washing hands that are actually conducted by respondents, especially regarding how to wash hands (Hirai et al., 2016; Wolf et $a l ., 2019)$. In addition, differences may also be caused by other factors that interact with the variables studied. For instance, related to sanitation variables, in previous studies, it was known that the results of interactions between components in sanitation (e.g. availability of water, latrines, trash cans, etc.) and between sanitation variables and other variables had different impacts on nutritional status (WHO, 2015).

The absence of a correlation found in this study was generally due to the fact that the two variables were indirectly related to nutritional status. As previously discussed, parenting patterns (including hand washing habits) and the environment (including home sanitation) are indirect causes. Both of these variables can affect nutritional status by first affecting the health status of children under two, namely by increasing the risk of a child getting infected with infectious diseases. These infectious diseases then have an impact on the nutritional status of the toddler in various ways, including loss of appetite, damage to certain body tissues, decreased immunity, malabsorption, and various other responses related to nutrition, energy and the body's metabolic processes, especially if it lasts for a long time and repetitive (Torlesse et al., 2016).

This infectious disease does not absolutely affect nutritional status. Previous systematic review studies have found a positive correlation between sanitation and various types of infection, but there are still some undefined gaps (Freeman et al., 2017). Before infectious diseases can affect nutritional status, it is still possible to find other variables that interrupt the correlation between the two. For example, even though a child is exposed to certain infectious diseases, his nutritional intake is still fulfilled and the body's immunity can still maintain his body condition, it is very likely that the outcome of nutritional status will not be affected. This statement supports the findings in this study which found that toddler with poor sanitation were all included in the group of good/over nutrition status.

\section{Research Limitations}

There are several limitations to this study. First, the saturated sampling technique used in this study causes the type of data produced to be limited and lacking in depth. However, this technique can provide an accurate description of the real conditions that exist in the population because the entire population is the sample of the study so there is no selection bias. Second, the variable indicator of hand washing and sanitation habits used in the questionnaire is not a standard indicator. This is due to several measurement components that cannot be carried out in the study due to constraints on tools and permits. Third, the use of self-report questionnaires allows for reporting bias because respondents tend to report positive things. To overcome this, the researchers worked around this by providing guidance and assisting respondents in the process of filling out the questionnaire.

\section{CONCLUSION}

The conclusion of this study was that the habit of washing the hands on Toddler's mother/main caretaker as well as basic home sanitation in toddler (under two years old/ Baduta) in Mojosari Village were mostly in good and safe condition. A fairly low component was found in the sanitation variable, which is related to the availability of trash bins and TPS. Furthermore, this study 
Anizah. Correlation Of Handwashing And Basic Household Sanitation Towards Nutritional Status Of Toddler (Under 2 Years Old/ Baduta) In Bojonegoro District

also found that there was no correlation between the variables of hand washing habits and basic home sanitation with nutritional status. The reason that may underlie this finding is due to the complex correlation with several other variables.

\section{SUGGESTION}

Recommendations that can be given for further research are 1) Perform an analysis of the same variables by correcting some of the limitations contained in this study 2) Conduct a deeper analysis of other variables that affect the correlation between hand washing habits, sanitation and nutritional status. 3) Analyze the correlation accompanied by variations in the age group or nutritional status index used.

\section{REFERENCES}

Afifah, T. et al. (2018) "Subnational regional inequality in access to improved drinking water and sanitation in Indonesia: results from the 2015 Indonesian National Socioeconomic Survey (SUSENAS)," https://doi.org/10.1080/16549716.201 8.1496972, $11 . \quad$ doi: 10.1080/16549716.2018.1496972.

Bappenas (2019) Kajian Sektor Kesehatan: Pembangunan Gizi di Indonesia, Kementerian PPN/Bappenas. Jakarta.

Celesta, A. G. dan Fitriyah, N. (2019) "Gambaran Sanitasi Dasar di Desa Payaman Kabupaten Bojonegoro Tahun 2016," Jurnal Kesehatan Lingkungan.

van Cooten, M. H. et al. (2019) "The association between acute malnutrition and water, sanitation, and hygiene among children aged 6-59 months in rural Ethiopia," Maternal and Child Nutrition, 15(1), hal. 1-8. doi: $10.1111 / \mathrm{mcn} .12631$.

Dagne, H. et al. (2019) "Hand washing practice at critical times and its associated factors among mothers of under five children in Debark town, northwest Ethiopia, 2018," Italian journal of pediatrics, 45(1), hal. 120. doi: 10.1186/s13052-019-0713-z.

Freeman, M. et al. (2014) "Hygiene and health: systematic review of handwashing practices worldwide and update of health effects," Tropical Medicine and International Health, 19,
JPH RECODE March 2022; 5 (2): 62-72

http://e-journal.unair.ac.id/JPHRECODE

http://dx.doi.org/10.20473/jphrecode.v5i 2.25198

hal. 906-16.

Freeman, M. C. et al. (2017) "The impact of sanitation on infectious disease and nutritional status: A systematic review and meta-analysis," International Journal of Hygiene and Environmental Health, 220(6), hal. 928-949. doi: 10.1016/j.ijheh.2017.05.007.

$\begin{array}{lrr}\text { Hariyanto dan Ariyani } & (2014) \\ \text { "PENGELOLAAN SAMPAH } & \text { DI } \\ \text { KOTA } & \text { SEMARANG } & \text { UNTUK } \\ \text { MENUJU } & \text { KOTA BERSIH," } & \text { Jurnal } \\ \text { Geografi : } & \text { Media } & \text { Informasi } \\ \text { Pengembangan dan } & \text { Profesi } \\ \text { Kegeografian. } & & \text { doi: } \\ \text { 10.15294/jg.v11i2.8031. } & \end{array}$

Hirai, M. et al. (2016) "Exploring Determinants of Handwashing with Soap in Indonesia: A Quantitative Analysis," International Journal of Environmental Research and Public Health, 13(9), hal. 868. doi: 10.3390/ijerph13090868.

Water org. Indonesia's Water Problems In 2020 (tanpa tanggal). Tersedia pada: https://water.org/our-impact/wherewe-work/indonesia/ (Diakses: 9 Juli 2021).

Izwardy, D. (2020) "Studi Status Gizi Balita," Balitbangkes Kemenkes RI.

Kementrian Kesehatan Republik Indonesia (2020) Peraturan Menteri Kesehatan Republik Indonesia Nomor 2 Tahun 2020 tentang Standar Antropometri Anak. Jakarta.

Komarulzaman, A., Smits, J. dan de Jong, E. (2017) "Clean water, sanitation and diarrhoea in Indonesia: Effects of household and community factors," Global Public Health, 12(9), hal. 1141-1155. doi: 10.1080/17441692.2015.1127985.

Kristiana, L. (2019) Hubungan tingkat pengetahuan dan ketersediaan sarana pembuangan sampah dengan perilaku membuang sampah rumah tangga di Desa Banyukuning Kecamatan Bandungan Kabupaten Semarang. Tersedia pada: https://lib.unnes.ac.id/34131/.

Langford, R., Lunn, P. dan Brick, C. P.- (2011) "Hand-washing, subclinical infections, and growth: A longitudinal evaluation of an intervention in Nepali slums," American Journal of Human Biology, 
Anizah. Correlation Of Handwashing And Basic Household Sanitation Towards Nutritional Status Of Toddler (Under 2 Years Old/ Baduta) In Bojonegoro District

23(5), hal. 621-629. doi: 10.1002/ajhb.21189.

Meliyanti, F. (2018) "Faktor-Faktor yang Berhubungan dengan Kepemilikan Saluran Pembuangan Air Limbah Rumah Tangga," Jurnal Aisyah: Jurnal Ilmu Kesehatan, 3(1), hal. 8794. doi: 10.30604/jika.v3i1.87.

Novitry, F. (Fera) dan Agustin, R. (Rizka) (2017) Determinan Kepemilikan Jamban Sehat di Desa Sukomulyo Martapura Palembang, Aisyah: Jurnal Ilmu Kesehatan. STIKES Aisyah Pringsewu. Tersedia pada: https://www.neliti.com/publications/21 7397/ (Diakses: 24 Januari 2021).

Raihan, M. J. et al. (2017) "Examining the relationship between socio- economic status , WASH practices and wasting," hal. 1-14. doi: 10.1371/journal.pone.0172134.

Septikasari, M. (2018) Status gizi anak dan faktor yang mempengaruhinya. Yogyakarta: UNY Press. Tersedia pada:

https://books.google.co.id/books?id=gj xsDwAAQBAJ\&dq=status+gizi+balita $\&$ hl=id\&source $=$ gbs_navlinks_s (Diakses: 26 Januari 2021).

Shrestha, S. K., Vicendese, D. dan Erbas, B. (2020) "Water, sanitation and hygiene practices associated with improved height-for-age, weight-for-height and weight-for-age z-scores among underfive children in Nepal," $B M C$ Pediatrics, 20(1), hal. 1-10. doi: 10.1186/s12887-020-2010-9.

Sinharoy, S. S. et al. (2016) "Child diarrhoea and nutritional status in rural Rwanda: a cross-sectional study to explore contributing environmental and demographic factors," Tropical Medicine and International Health, 21(8), hal. 956-964. doi: 10.1111/tmi.12725.

Suryani, L. (2017) "Faktor Yang Mempengaruhi Status Gizi Balita Di Wilayah Kerja Puskesmas Payung Sekaki Pekanbaru," Journal Of Midwifery Science.

The World Bank (2013) Improving nutrition through multisectoral approaches. Washington DC. Tersedia pada: http://documents.worldbank.org/curate d/en/2013/01/17211210/improving-
JPH RECODE March 2022; 5 (2): 62-72

http://e-journal.unair.ac.id/JPHRECODE

http://dx.doi.org/10.20473/jphrecode.v5i 2.25198

nutrition-through-multisectoral-

approaches.

Torlesse, H. et al. (2016) "Determinants of stunting in Indonesian children: Evidence from a cross-sectional survey indicate a prominent role for the water, sanitation and hygiene sector in stunting reduction," BMC Public Health, 16(1), hal. 1-11. doi: 10.1186/s12889-016-3339-8.

UNICEF (2019) United Nation Childern's Fund, Global Framework for Urban Water, Sanitation and Hygiene. New York.

UNICEF (2020) 2020 Global Nutrition Report: Action on equity to end malnutrition, The Global Nutrition Report's Independent Expert Group. Bristol.

WHO (2015) Improving nutrition outcomes with better water, sanitation and hygiene: practical solutions for policies and programmes. Geneva. Tersedia pada: https://apps.who.int/iris/bitstream/hand le/10665/193991/9789241565103_eng. pdf?sequence $=1$ (Diakses: 26 Januari 2021).

Widyastutik, O. (2017) "Faktor yang berhubungan dengan kepemilikan jamban sehat di Desa Malikian, Kalimantan Barat," Jurnal Ilmu Kesehatan Masyarakat, 13(1). doi: https://doi.org/10.19184/ikesma.v13i1. 5223.

Wolf, J. et al. (2019) "Handwashing with soap after potential faecal contact: global, regional and country estimates," International Journal of Epidemiology, 48(4), hal. 1204-1218. doi: 10.1093/ije/dyy253.

World Food Programme (2020) Executive board draft Indonesia country strategic plan ( $2019-2023$ ).

Wulansari, N. T. dan Parut, A. A. (2019) "Pengendalian Jumlah Angka Mikroorganisme Pada Tangan Melalui Proses Hand Hygiene," Jurnal Media Sains, 3(1), hal. 7-13. Tersedia pada: https://jurnal.undhirabali.ac.id/index.p $\mathrm{hp} / \mathrm{mp} 3 /$ article/view/694. 
Anizah. Correlation Of Handwashing And Basic Household Sanitation Towards Nutritional Status Of Toddler (Under 2 Years Old/ Baduta) In Bojonegoro District
JPH RECODE March 2022; 5 (2): 62-72

http://e-journal.unair.ac.id/JPHRECODE

http://dx.doi.org/10.20473/jphrecode.v5i2.25198 